\title{
Study on Party Spirit Cultivation of College Student Party Members from the Perspective of Strengthening the Moral Education and Cultivating People-Taking Qinghai Normal University as an Example
}

\author{
Haixia Jin \\ Institute of Physical Education, Qinghai Normal University, Qinghai, China \\ Email:jy_liu_edit@hotmail.com
}

How to cite this paper: Jin, H.X. (2021) Study on Party Spirit Cultivation of College Student Party Members from the Perspective of Strengthening the Moral Education and Cultivating People-Taking Qinghai Normal University as an Example. Open Access Library Journal, 8: e7803.

https://doi.org/10.4236/oalib.1107803

Received: July 29, 2021

Accepted: August 24, 2021

Published: August 27, 2021

Copyright $\odot 2021$ by author(s) and Open Access Library Inc.

This work is licensed under the Creative Commons Attribution International License (CC BY 4.0).

http://creativecommons.org/licenses/by/4.0/

\section{(c) (i) Open Access}

\begin{abstract}
In the new era, the party central committee attaches great importance to the Party's own construction and development. As the youngest and most active member of the party, the college student party member shoulders the important mission of the future construction and development of the motherland. It is an urgent problem to be solved about how to strengthen the college students' party spirit cultivation of all ethnic groups and gather the strength from them in the process of training and developing college party members. From the perspective of "strengthening the moral education and cultivating people", college students party members are the breakthrough point. Through investigating the students from different grade, major and nation with questionnaire investigation, logical analysis and other methods, we can grasp the currency of university students party members in self-cognition, self-education, self-improvement and self-development etc.; then we can seek effective ways in the training and development of new party members in colleges and universities.
\end{abstract}

\section{Subject Areas \\ Politics, Sociology \\ Keywords \\ Cultivate People by Virtue, College Student Party Members, Party Spirit Cultivation}




\section{Introduction}

In the new era, the CPC Central Committee with Comrade Xi Jinping as the core attaches great importance to and cares about the growth of young people. As the main force of the young generation, college students shoulder the great mission of strengthening the motherland and national rejuvenation. Since the 18th National Congress of the CPC, "cultivating people by virtue" has become the main theme of education. In his speech to the national Education Conference, Xi Jinping said: "We should take the effectiveness of cultivating people by virtue as the fundamental standard for testing all the work of schools. With cultivating people as the core and virtue as the fundamental, we should constantly train socialist builders and successors who are well-developed in moral, intellectual, physical, aesthetic and labor." [1] As the main position of moral cultivation, college students as activists and advanced forces among students, and "moral education" as one of the important carriers of college students party members, it plays a crucial role in improving the party spirit of student party members and the historical mission of student party members.

"Cultivating people by virtue is the foundation of colleges and universities. College culture should closely focus on the fundamental task of cultivating people by virtue, find the right focus, recognize the foothold, choose a good entry point, and consolidate the point of force." [2] As the backbone of college students, college student party members are the entry point and power point for universities to cultivate people by virtue. On the basis of clarifying the scope of party spirit cultivation, taking Qinghai Normal University as an example, the questionnaire was designed with "Party spirit cultivation of college student party members" as the main content. In order to ensure the reliability and effectiveness of this questionnaire, before forming a formal questionnaire, 41 target-related questions were set to test the questionnaire, and the reliability and validity analysis of the test results was conducted, and 26 questionnaire items were finally selected according to the analysis results. In order to ensure the reliability and effectiveness of the questionnaire, 41 goal related questions were set to test the questionnaire before the formal questionnaire was formed, and the reliability and validity of the test results were analyzed. A total of 26 questionnaire items were selected according to the analysis results. The questionnaire takes the party constitution as the standard, adheres to the standard of Communist Party members, and combines the characteristics and reality of college student party members to mainly understand the understanding of Party members, as well as the situation of self-cultivation, self-discipline, self-awareness, self-cultivation, self-management, self transformation, self-development, self-practice and striving to be a pioneer model as a party member, so as to master the current party spirit cultivation of college students. A total of 800 questionnaires were distributed and 753 valid questionnaires were recovered. The recovery rate of the effective questionnaire was 95.08\%. Using stratified random sampling, 792 college student party members (including 98 ethnic minority students) from 46 majors and four grades in 17 colleges were investigated by questionnaire. 800 questionnaires were issued, 753 
valid questionnaires were recovered and $95.08 \%$ efficient. Overall, the team of college student party members is positive and energetic, but due to the bad social environment, the impact of complex network information, untimely education and guidance and other factors, there is still a certain gap between college student party members and the Party member standards of the new era in terms of value orientation, theoretical literacy and service awareness. Therefore, how to enhance the party spirit cultivation of college student party members from the perspective of Building Morality and cultivating people has become an urgent practical problem to be solved.

\section{Current Status and Existing Problems of Student Party Members of Qinghai Normal University}

\subsection{Self-Cognition Is Not Thorough, the Ideals and Beliefs Are Not Firm}

The vast majority of student Party members in the school have clear learning objectives, correct learning attitude, clear the rights and obligations of Party members.62.18\% of the students have firm political ideals. However, more than $30 \%$ of them have impure motives to join the party, have no lofty political ideals, and have utilitarianism and hedonism. How to strengthen the education of political belief and ideals and beliefs, cultivate student Party members' road, theory, system and cultural confidence, has become an important direction of college student Party members training (Table 1).

\subsection{Self-Education Is Not In-Depth, Theoretical Learning Is Not Active}

In the study of Marxist theory, $73.61 \%$ of the students rely on ideological and political public subjects. In terms of current political learning and ethnic education, $85.64 \%$ of the student Party members are conducted through the situation policy courses and the learning meetings organized by the college. The proportion of students' active self-study is small, and only 13 respondents have studied the Marxist classics. $49.86 \%$ of student Party members have understanding or basic understanding of the connotation of Party spirit cultivation, and $41.89 \%$ are not familiar with the content of the Party Constitution. Thus it can be seen that the student party member political theory learning is mostly passive, resulting in the learning content is not systematic, in-depth and timely. How to stimulate the initiative and enthusiasm of students "political theory learning, guide students to form good learning habits, and cultivate students" core consciousness and international vision has become a major theme of Party building in universities in the new era (Table 2).

\subsection{Self-Transformation Is Not Comprehensive, the Service Awareness Is Weak}

"Stay true to the original aspiration and keep our mission firmly in mind" is the 
Table 1. Party members' motivation and political belief in joining the party.

\begin{tabular}{lcccc}
\hline \multirow{2}{*}{ Questionnaire topic } & \multicolumn{4}{c}{ Option percentage } \\
\cline { 2 - 5 } & A & B & C & D \\
\hline 1. What is your intention to join the party? & $60.44 \%$ & $23.63 \%$ & $12.28 \%$ & $3.65 \%$ \\
2. What do your political beliefs prefer? & $62.18 \%$ & $18.33 \%$ & $14.26 \%$ & $5.23 \%$ \\
\hline
\end{tabular}

Table 2. Party members' self-study and self-education.

\begin{tabular}{|c|c|c|c|c|}
\hline \multirow{2}{*}{ Questionnaire topic } & \multicolumn{4}{|c|}{ Option percentage } \\
\hline & A & B & $\mathrm{C}$ & $\mathrm{D}$ \\
\hline 3. What way do you study Marxist theory? & $73.61 \%$ & $14.42 \%$ & $10.24 \%$ & $1.73 \%$ \\
\hline $\begin{array}{l}\text { 4. What way do you learn about current politics and } \\
\text { ethnic education? }\end{array}$ & $85.64 \%$ & $8.37 \%$ & $3.26 \%$ & $2.37 \%$ \\
\hline 5. Do you know the content of the Party Constitution? & $11.27 \%$ & $21.62 \%$ & $25.22 \%$ & $41.89 \%$ \\
\hline $\begin{array}{l}\text { 6. Do you know what aspects of the party spirit } \\
\text { cultivation of the party members include? }\end{array}$ & $11.20 \%$ & $23.62 \%$ & $26.24 \%$ & $38.94 \%$ \\
\hline
\end{tabular}

requirement of every Party member in the new era [3]. More than $90 \%$ of student Party members abide by the Party Constitution and rules, school discipline rules, and can require themselves according to the standards of Party members. $75.93 \%$ of the students are able to actively participate in various Party member activities organized by the colleges and schools. $48.79 \%$ of the student Party members are subject to student supervision. But we must pay attention to the bad habits and behavior of the students around us, many student party members turn a blind eye and are indifferent. In the evaluation process of awards and grants, $58.69 \%$ of student party members put personal interests first. In daily life, a small number of Party members have the idea of benefit and no profit avoidance. Therefore, how to enhance the service consciousness of student party members and the overall situation consciousness has become the key to improve the party spirit cultivation of student party members (Table 3 ).

\subsection{Self-Development Is Not Perfect, and the Ability to Distinguish Right from Wrong Is Insufficient}

In the activities held by the school, $84.82 \%$ of the student party members can take the lead, but they play a small role in innovation and entrepreneurship and various skills competitions. When there is bad atmosphere and misconduct around, $75.67 \%$ of student party members cannot quickly make a correct and reasonable judgment to resist the bad atmosphere. In terms of cultural knowledge and professional ability, more than $90 \%$ of student party members have good scores in cultural courses, but their ability to combine theory with practice is poor, and they lack long-term planning for self-growth. How to improve the ability of student party members to distinguish right from wrong and improve the comprehensive quality of student party members is the core element of enhancing the party spirit cultivation in colleges and universities (Table 4). 
Table 3. The vanguard and exemplary role of party members and their service to students.

\begin{tabular}{|c|c|c|c|c|}
\hline \multirow{2}{*}{ Questionnaire topic } & \multicolumn{4}{|c|}{ Option percentage } \\
\hline & A & B & $\mathrm{C}$ & $\mathrm{D}$ \\
\hline 7. Have you ever violated the school-level school rules? & $97.93 \%$ & $2.06 \%$ & $0.01 \%$ & $0.00 \%$ \\
\hline $\begin{array}{l}\text { 8. Do you abide by the Party Constitution and Party rules } \\
\text { and require yourself according to the standards of } \\
\text { Party members? }\end{array}$ & $74.78 \%$ & $18.07 \%$ & $6.26 \%$ & $0.89 \%$ \\
\hline $\begin{array}{l}\text { 9. Do you actively participate in the Party member activities } \\
\text { organized by the school and the college on time? }\end{array}$ & $28.56 \%$ & $47.37 \%$ & $17.22 \%$ & $6.85 \%$ \\
\hline $\begin{array}{l}\text { 10. As a party member, can you accept the supervision of } \\
\text { your classmates? }\end{array}$ & $19.87 \%$ & $28.92 \%$ & $35.02 \%$ & $16.19 \%$ \\
\hline $\begin{array}{l}\text { 11. Will you take the initiative to humble your other } \\
\text { students in the grant evaluation? }\end{array}$ & $17.21 \%$ & $24.10 \%$ & $42.16 \%$ & $16.53 \%$ \\
\hline
\end{tabular}

Table 4. Party members' own quality.

\begin{tabular}{|c|c|c|c|c|}
\hline \multirow{2}{*}{ Questionnaire topic } & \multicolumn{4}{|c|}{ Option percentage } \\
\hline & A & B & $\mathrm{C}$ & $\mathrm{D}$ \\
\hline $\begin{array}{l}\text { 12. Do you think you take the lead in the activities held at } \\
\text { the school? }\end{array}$ & $67.93 \%$ & $16.89 \%$ & $12.86 \%$ & $2.32 \%$ \\
\hline $\begin{array}{l}\text { 13. Have you ever participated in an innovation and } \\
\text { entrepreneurship competition? }\end{array}$ & $3.47 \%$ & $2.19 \%$ & $0.71 \%$ & $0.01 \%$ \\
\hline 14. Have you ever played in the skills competitions? & $6.25 \%$ & $4.08 \%$ & $2.73 \%$ & $0.87 \%$ \\
\hline $\begin{array}{l}\text { 15. Can you resist bad practices when there are bad } \\
\text { practices and misconduct around you? }\end{array}$ & $2.46 \%$ & $21.87 \%$ & $12.76 \%$ & $62.91 \%$ \\
\hline 16. Have you ever failed a course? & $82.73 \%$ & $14.42 \%$ & $2.03 \%$ & $0.82 \%$ \\
\hline $\begin{array}{l}\text { 17. Have you learned more combinations of theory and } \\
\text { practice? }\end{array}$ & $5.63 \%$ & $24.69 \%$ & $41.83 \%$ & $27.85 \%$ \\
\hline
\end{tabular}

\section{The Effective Path to Improve the Party Spirit Cultivation of College Students under the Perspective of Cultivating People by Virtue}

Strengthening the party spirit cultivation of college student Party members is the key to maintain the advanced nature of the Communist Party members. Under the background of cultivating people by virtue, it is particularly urgent to combine moral education with student party building, and explore a new path to cultivate the comprehensive ability of student party members and improve the party spirit cultivation.

\subsection{Create a Positive and Healthy Network Education Environment, to Create a Clean and Upright Campus Cultural Atmosphere}

In the information age, the network culture affects the campus culture. All kinds of information troubles and affects the students. The state should strengthen the supervision of network information to ensure that students in a benign and 
healthy network environment, use Weibo, WeChat, QQ, Baidu and other software to understand current affairs and politics, pay attention to cutting-edge trends, and learn political theoretical knowledge. Colleges and universities should also strengthen the campus network supervision, to create a healthy and upward network public opinion environment. At the same time, make full use of the network platform and campus radio, do a good job in the ideological and political education and value guidance of student Party members, cultivate a Party member that can lead the campus public opinion, carry forward advanced deeds, spread positive energy, and radiate the surrounding students. Under the guidance of Xi Jinping Thought on Socialism with Chinese Characteristics for a New Era, student Party members will become qualified Party members in the new era who speak politics, have ideals, understand rules, understand laws, learn knowledge, and serve the people. In addition, colleges should create a good campus environment for students, organize various forms of organization, strong practical party and league activities, so that student party members gather strength, take the head, do a good job of a good example, and can drive the surrounding students to actively close to the party organization.

\subsection{Deeply Implement the "Moral Education Promotion Project" and Build a Long-Term Party Spirit Guidance Mechanism}

In October 2015, Qinghai Normal University implemented the "moral education promotion project" and formulated the Interim Measures for Moral Education Practice Credits of Qinghai Normal University Based on the implementation plan of Qinghai Normal University on comprehensively constructing the civilized self-cultivation project for college students. Through the implementation of a series of measures, with the student party members as the starting point, the students' spiritual civilization state has been greatly improved. In a period of time, the advanced nature and demonstration role of the model have been effectively played. Therefore, the further implementation of the "moral education promotion project", in strict accordance with the procedures to develop party members, keep the process of developing party members, in-depth heart to heart talk, make full use of the network platform to carry out online supervision and offline education, to investigate the party activists, build teacher guidance, students independent, student supervision of long-term guidance mechanism.

\subsection{Enrich the Methods and Carrier of Party Spirit Education, Enhance the Political Identity of Student Party Members}

To implement the fundamental task of cultivating people through virtue, we focus on the integration of knowledge and action. [4] As a college student Party member in the new era, we should earnestly study and understand Xi Jinping Thought on Socialism with Chinese Characteristics for a New Era, master the systematic Marxist theoretical knowledge, arm themselves with scientific methods, advanced ideas and solid knowledge, and improve their Party spirit cultivation. The school party organization should carry out targeted party member 
activities according to the actual situation of the students. Take the combination of online and offline, not only to organize students to learn the party's line, policy, policy, and to theory and practice to encourage student party members according to what learned content, carry out practice and volunteer service, make student party members' practice consciousness and service consciousness normalized, enhance the party spirit identity of student party members.

\section{Conclusion}

As the fundamental task of education, "Cultivate people by virtue" is a long-term systematic project through every stage of the education of student party members. Student party members are the most energetic and creative among the party members, and are the main body of thought of the Chinese nation, especially the people of all ethnic groups in the plateau, as they move together towards civilization and progress to realize the great rejuvenation of the Chinese nation, guide student party members to participate in timely and correct political theory studies, and help them to understand and internalize the party's ideology and theory, so that their theory and practice can be combined and knowledge and practice can be united. Through effectively enhancing the cohesiveness, striving spirit and sense of historical mission of student party members, improving their service consciousness and comprehensive qualities, and cultivating a sense of overall situation and world vision, a team of student party members with firm political stance, pure political beliefs, strong principles, strict discipline and high cultivation can be built from the source. However, the content of this paper is limited to the results of the questionnaire survey, coupled with the unbalanced development of colleges and universities in different regions, and the ability and quality of student party members are also different to some extent. Based on this, the author will continue to study related contents.

\section{Conflicts of Interest}

The author declares no conflicts of interest.

\section{References}

[1] Xi, J.P. (2018) Adhere to the Socialist Path of Education Development with Chinese Characteristics to Train Socialist Builders and Successors for the All-Round Development of Morality, Intelligence, Body, Beauty, Beauty and Labor. People's Daily.

[2] Liu, X.C. and Zhao, H.L. (2018) Research on the Educational Function of College Culture. Thought Education Research, December 12, Studies in Ideological Education: Total Issue 294.

[3] Wang, N. (2013) Research on the Party Spirit Education of College Student Party Members. Shandong University, Jinan.

[4] Fan, G.R. (2019) Thinking on Implementing the Fundamental Task of Cultivating People by Education in the New Era-Learn from the Important Speech of General Secretary Xi Jinping at the National Education Conference. Moral Education China. 